Daria R. Yunda

master's degree student

Elena Yu. Pishkova

candidate of philosophical sciences, associate professor, lecturer Institute of Philology, Journalism and Intercultural Communications of FSAEI of HE "Southern Federal University" Rostov-on-Don, Rostov region

DOI $10.31483 / r-98741$

\title{
CLASSIFICATION OF NON-EQUIVALENT VOCABULARY
}

Abstract: the article deals with studying the classification of non-equivalent vocabulary by L.S. Barkhudarov and analysing the English texts of legal articles. Based on the present research, the authors came to a conclusion about the frequency of usage of certain group of non-equivalent vocabulary in juridical texts.

Keywords: non-equivalent vocabulary, legal translation, classification of nonequivalent vocabulary.

\section{Юнда Дарья Руслановна магистрант}

\section{Пишкова Елена Юрьевна}

канд. филол. наук, доцент, преподаватель Институт филологии, журналистики и межкультурной коммуникации ФГАОУ ВО «Южный федеральный университет» г. Ростов-на-Дону, Ростовская область

\section{КЛАССИФИКАЦИЯ БЕЗЭКВИВАЛЕНТНОЙ ЛЕКСИКИ}

Аннотация: статья посвящуена изучению классификации безэквивалентной лексики Л.С. Бархударова и анализу англоязычных юридических статей. По результатам проведенного авторами исследования был составлен вывод о частоте использования безэквивалентной лексики определенной группь в юридических текстах. 
Ключевые слова: безэквивалентная лексика, юридический перевод, классификаиия безэквивалентной лексики.

Nowadays research in the legal industry is of particular interest to linguists and translators. This is due to the rapid development of relations between countries and the strengthening of ties in various areas of activity. Legal language reflects the fundamental elements and patterns of the country's culture. For this reason, when translating legal texts, it is necessary to study thoroughly details of foreign culture, which are necessary both for accurate translation and for understanding which phrases cannot be rendered verbatim. Such phrases represent non-equivalent vocabulary.

Abundance of various approaches to both the definition of the concept "nonequivalent vocabulary" and the classification of the latter brings discord into this field and complicate communication between modern researchers. This discord often makes it difficult to share materials. It is therefore important to maintain interest in translating non-equivalent vocabulary in an attempt to come to a single system that meets all the requirements.

Vilen Naumovich Komissarov defines the term "non-equivalent vocabulary" in the following way: "units of the source language that do not have regular correspondences in the target language". In this paper we adhere to this definition [2].

L.S. Barkhudarov distinguishes the following categories of lexical units which relate to non-equivalent vocabulary:

The first category: proper names, geographical names, names of institutions, organizations, newspapers, little-known names and surnames, including the characters of works (especially charactonyms) etc.;

The second category: realias - words that denote objects, concepts or situations that do not exist in the target language in view of cultural differences (for example, the names of national dishes, types of national clothes);

The third category: accidental gaps are lexical units of the source language which for some reason do not correspond to the vocabulary of the target language [1].

We believe that L.S. Barkhudarov classifies non-equivalent vocabulary in the most succinct way. For this reason, we adhere to this classification in our research. 
The English texts of legal articles written by practicing lawyers of USA and taken from Legal Resources web-site served as our study material.

Based on the classification of non-equivalent vocabulary according to L.S. Barkhudarov, we selected non-equivalent vocabulary by the continuous sampling method.

We have ranged the following concepts in the first category:

- the names of states and cities ("When Is Workers' Compensation Required Under Alabama code", "Dan Reynolds sat down for an interview with KXL to talk about the process of a blood draw in a DUI Investigation in Oregon");

- the names and surnames (Many of our past clients here at the Law Office of John Freeman have encountered such circumstances).

We have ranged the following concepts in the second category:

- the national currency ("That's about $\$ 130,000$ to $\$ 180,000$ for a new tractor (cab) and $\$ 30,000$ to $\$ 80,000$ for a new trailer");

- the measures of length and weight ("In Texas, an 18-wheeler can legally weigh 80,000 pounds", "The most common trailer length on an 18-wheeler is 53 feet», «New F-150s can carry from 1,745 to 2,238 lbs. payload").

Besides, we have found the following concepts:

- "an 18-wheeler". According to the Merriam-Webster Dictionary, this concept means a tracking rig consisting of a tractor and a trailer and typically having eighteen wheels (an eight-wheeled truck with a trailer). In Russia there is no such a concept because the legal acts regulating traffic safety imply length of the vehicle limits. In the United States and Australia there are no such strict restrictions, so in these countries this concept is widespread;

- "The U.S. EEOC (Equal Employment Opportunity Commission)".

We have ranged the following concepts in the third category:

- "Felony". The Legal Dictionary gives us the following definition of "felony": "The classification of the most serious types of crimes. Covering a wide range of criminal acts, felonies often involve crimes involving physical harm, or large scale theft and fraud". (A category of serious grievous crimes. Covering a large number of criminal 
offenses, felonies often involve damage to human health, major theft and fraud). This concept is characteristic of Anglo-Saxon law;

- "Subpoena”. Legal Dictionary: "A legal document ordering a person to appear in court, or to provide the court with specific documents".

After we had classified 125 cases of using non-equivalent vocabulary that we found in the articles of practicing lawyers of the United States, we came to the conclusion that the main part is accounted for by the first category (according to the classification of L.S. Barkhudarov) which includes the names of cities and states, the names and surnames. Of the total number this category made up $52 \%$. We can explain the prevalence of the first category by the fact that in the United States the mention of a state is of great importance because each state has its own legislation. The second category, which includes realias, made up $32 \%$ of the total. The third category, which includes accidental gaps, made up 16\% (figure 1).

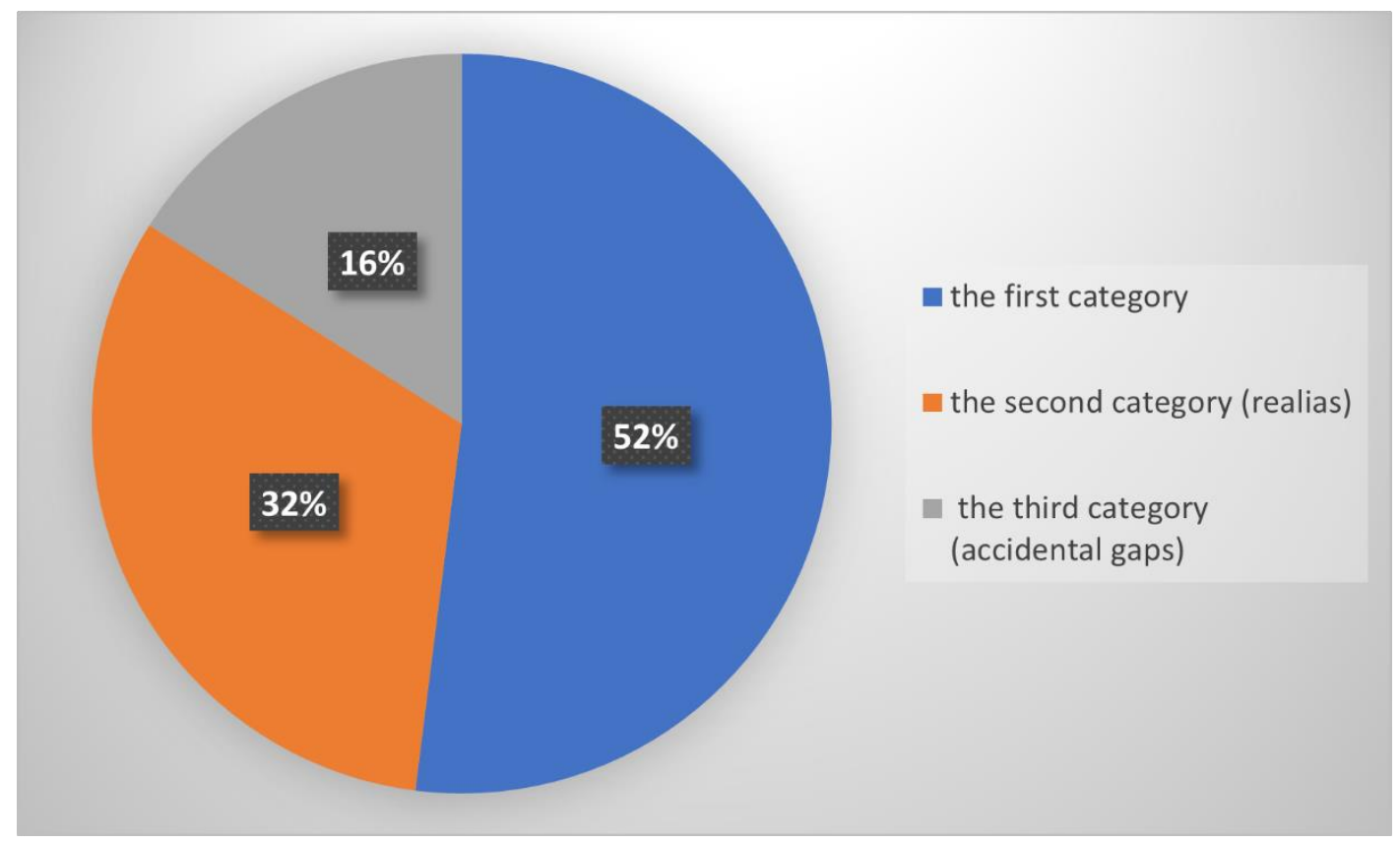

Fig. 1. The correlation between categories of non-equivalent vocabulary (according to L.S. Barkhudarov`s classification)

\section{References}

1. Barkhudarov L.S. Language and translation (questions of general and specific theory of translation). - M.: International relations, 1975. - 93 p. 
2. Komissarov V.N. Theory of translation (Linguistic aspects). - M.: Higher School, 1990. - 162 p.

3. Luttseva M.V. English legal terminology and ways of its translation into Russian // VSU Vestnik. Series: Linguistics and Intercultural Communication. - 2007. No. 2, Part 1. Pp. 110-113.Список литературы

1. Бархударов Л.С. Язык и перевод (вопросы общей и частной теории перевода) / Л.С. Бархударов. - М.: Международные отношения, 1975. - 93 с.

2. Комиссаров В.Н. Теория перевода (лингвистические аспекты) / В.Н. Комиссаров. - М.: Высшая школа, 1990. - 162 с.

3. Лутцева М.В. Английская юридическая терминология и способы её перевода на русский язык / М.В. Лутцева // Вестник ВГУ. Серия: Лингвистика и межкультурная коммуникация. - 2007. - №2, ч. 1. - С. 110-113. 